IRSTI 06.73.15

Ermekbaeva B.Zh. ${ }^{1}$, Mukhadil Zh.E. ${ }^{2}$

1acting professor, e-mail: bayan.ermekbaeva@kaznu.kz ${ }^{2}$ master student, e-mail: zhmukhadil@gmail.com

1,2Al-Farabi Kazakh National University, Kazakhstan, Almaty

\title{
HARMONIZATION OF TAX SYSTEMS OF THE MEMBER STATES OF THE EURASIAN ECONOMIC UNION
}

The relevance of this article is reflected in the need for a comprehensive study and comparative analysis of the tax systems of the countries of the Eurasian economic Union in the context of globalization of the world economy. The main purpose of the article is to conduct a comparative analysis of the elements of the tax systems of the EAEU countries and identify the existing problems that prevent harmonization. The object of the article is the tax systems of the countries of the Eurasian economic Union.

Analyzing the data from the article on VAT, significant problems were identified. Taking into account the special importance of VAT in foreign trade, the necessary measures are proposed to solve the problems of unification of the tax legislation of the member States of the Eurasian economic Union.

This article contains introductory information for future research on the harmonization of tax systems. The Eurasian economic Union is a fundamentally new object of socio-economic research, so the study of the peculiarities of its formation and functioning, as well as its place in the global process of globalization is of great scientific interest.

Tax relations are present in all sectors of the world economy, therefore in the conditions of globalization of the world economy, it is important to consider the tax implications accept integration solutions. It is well known that the main components of the tax system are indirect taxes, in particular VAT. The study of the state of VAT collection and the development of new approaches to improve, in our opinion, attracts a certain scientific and practical interest in the integration of the tax systems of the participating countries.

Key words: Eurasian economic Union, globalization, tax system harmonization, integration, indirect taxes, VAT.

\author{
Ермекбаева Б.Ж. ${ }^{1}$, мұхаділ Ж.Е. ${ }^{2}$ \\ ${ }^{1}$ профрессор м.а., e-mail: bayan.ermekbaeva@kaznu.kz \\ ${ }^{2}$ магистрант, e-mail: zhmukhadilegmail.com \\ 1,2әл-Фараби атындағы Қазақ, ұлттық университеті, Қазақстан, Алматы қ.
}

ЕАЭО қатысушы елдердің салық жүйелерін гармонизациялау

Мақаланың өзектілігі әлемдік экономиканың жаһандануы жағдайында Еуразиялық экономикалық одаққа мүше елдердің салық жүйелерін жан-жақты зерттеу және салыстырмалы та^дау жүргізу қажеттілігінде көрініс табады. Мақаланың негізгі мақсаты - ЕАЭО елдерінің салық, жүйесінің элементтеріне салыстырмалы та^дау жүргізу және гармонизацияға кедергі келтіретін проблемаларды анықтау. Мақала объектісі Еуразиялық экономикалық одақ елдерінің салық жүйелері болып табылады.

ҚҚС қатысты мақаладан алынған мәліметтерді талдай отырып, елеулі проблемалар анықталды. Сыртқы сауданы жүзеге асыру кезінде ҚҚС-ның ерекше маңыздылығын ескере отырып, Еуразиялық экономикалық одаққа мүше елдердің салық заңнамасын біріздендіру проблемаларын шешу үшін қажетті шаралар ұсынылды.

Бұл мақала салық жүйелерін үйлестіру бойынша болашақ, зерттеулер үшін таныстыру ақпаратын қамтиды. Еуразиялық экономикалық одақ - әлеуметтік-экономикалық зерттеулердің принципті жаңа объектісі, сондықтан оның қалыптасуы мен жұмыс істеу ерекшеліктерін зерттеу, сондай-ақ, әлемдік жаһандану үлерісіндегі орын үлкен ғылыми қызығушылық тудырады. 
Салық қатынастары әлемдік шаруашылықтың барлық салаларында бар, сондықтан әлемдік экономиканың жаһандануы жағдайында қабылданатын интеграциялық, шешімдердің салықтық салдарын ескеру маңызды. Салық жүйесіндегі негізгі құрауыштар жанама салықтар, атап айтқанда ҚҚС болып табылатыны жалпыға мәлім. ҚҚС алу жағдайын зерделеу және жетілдіру бойынша жаңа тәсілдерді әзірлеу, біздің ойымызша, қатысушы елдердің салық жүйелерін интеграциялау жағдайында белгілі бір ғылыми-практикалық қызығушылық тудырады.

Түйін сөздер: Еуразиялық экономикалық, одақ, жаһандану, салық, жүйесін гармонизациялау, интеграция, жанама са^ықтар, ҚҚС.

\author{
Ермекбаева Б.Ж. ${ }^{1}$, МұхаАіл Ж.Е. ${ }^{2}$ \\ ${ }^{1}$ и.о. профрессора, e-mail: bayan.ermekbaeva@kaznu.kz \\ ${ }^{2}$ магистрант, e-mail: zhmukhadilegmail.com \\ 1,2Казахский национальный университет имени аль-Фараби, Казахстан, г. А^маты
}

Гармонизация налоговых систем стран-участниц ЕАЭС

\begin{abstract}
Актуальность Аанной статьи отражается в необходимости всестороннего изучения $и$ проведения сравнительного анализа налоговых систем стран Евразийского экономического союза в условиях глобализации мировой экономики. Основная цель статьи - провести сравнительный анализ элементов налоговых систем стран ЕАЭС и выявить имеющиеся проблемы, препятствующие гармонизации. Объектом статьи яв^яются налоговые системы стран Евразийского экономического союза.

Анализируя данные из статьи касательно НАС, были выявлены значительные проблемы. Учитывая особую важность НАС при осуществлении внешней торгов^и, А^я решения проблем унификации налогового законодательства стран-членов Евразийского экономического союза предложены необходимые меры.

Аанная статья содержит ознакомительную информацию для будущих исследований по гармонизации налоговыхсистем. Евразийский экономический союз-принципиа^ьно новый объект социально-экономических исследований, поэтому изучение особенностей его формирования и функционирования, а также место в мировом процессе глобализации представляет большой научный интерес.

Налоговые отношения присутствуют во всех сферах мирового хозяйства, поэтому в условиях глобализации мировой экономики важно учитывать налоговые последствия принимаемых интеграционных решений. Общеизвестно, что основным составляющим в налоговой системе яв^яются косвенные налоги, в частности НАС. Изучение состояния взимания НАС и разработка новых подходов по совершенствованию, на наш взгляА, привлекает определенный научнопрактичный интерес в условиях интеграции налоговых систем стран-участниц.

Кмючевые слова: Евразийский экономический союз, глобализация, гармонизация налоговой системы, интеграция, косвенные налоги, НАС.
\end{abstract}

\section{Introduction}

Taxes are the main and most effective instrument of state regulation in the sphere of interstate economic relations. This is due to the growth of transnational corporations and financial and industrial groups and their influence on the world economy, the deepening and development of specialization and cooperation of production on an international scale. Under the economic Union, in addition to the General customs policy and the free movement of resources, it is necessary to coordinate macroeconomic policy in key areas, such as currency, budget, tax, etc.

In modern conditions in the world economy with the development of regionalization and integration appeared the category of new economy - globalization.
Globalization of the economy creates additional problems in the implementation of financial and tax policies.

In the context of globalization, there is a certain harmonization of tax systems and tax policy. There will be a unification of different countries' tax systems, which requires the harmonization of the main indicators and mechanisms of the tax system, the tax law of different countries, the solution of double taxation and taxation of investment activities.

The experience of economic integration within the European Union demonstrates that taxes within the framework of state regulation began to play a qualitatively new role, i.e. the tax has an external function. The new function of the tax can be described as an integration function aimed at regulating foreign economic and foreign trade 
operations. Taxes are becoming one of the tools for the formation of a common economic space for States connected by economic, regional and political interests.

Harmonization of tax systems is a complex and lengthy process involving the unification of indirect and direct taxation, harmonization of tax legislation, the development of a unified tax classification system, the creation of various international institutions and organizations dealing with tax issues. In the world practice, the experience of the member States of the European Union can be noted as vivid example of harmonization of tax systems. Harmonization of tax systems between EU member States began with the unification of indirect taxation.

In modern conditions, with the formation of the EAEU, one of the main problems is the problem in the field of harmonization of the tax system.

Globalization of the economy is impossible without the unification of the tax systems of the member States, as the tax system and the tax mechanism supposes adaptation to universal requirements.

This problem is of particular relevance within the framework of the EAEU.

In the framework of the EAEU harmonization of the customs tariffs to a certain extent integrated, but in the area of taxes, especially indirect taxes harmonization is still not solved.

\section{Materials and methods}

This article uses as a material normative legal acts (tax codes of the Republic of Kazakhstan, Russian Federation, the Republic of Kyrgyzstan, the Republic of Armenia and the Republic of Belarus) and data from the official Internet resources of the tax authorities of the member States of the Eurasian economic Union, also studied the works of scientistseconomists of the CIS and foreign countries.

The first studied the work of economists on this topic. Then the interest rates and the share of VAT in the tax revenues of the countries were compared, as indirect taxes play an important role in the harmonization of tax systems. Analyzing the state of VAT collection within the EAEU countries, the main problems were identified and ways to solve these problems were proposed. A comparative analysis of some elements (namely: levels of the tax system, types of taxes, composition of tax authorities, special tax regulations) of the tax systems of the five countries is also given. The problems hindering the harmonization of tax systems are revealed.
In writing the work, depending on the characteristics of the tasks to be solved, various methods of economic research were used: abstract and logical-in setting the goals and objectives of the research; comparative analysis - in determining the positive and negative trends in the implementation of the Eurasian integration project and in the study of other problems considered in the work; inductive and deductive methods - in identifying the mutual benefits of EAEU formation for its members and potential partners.

The article uses the methods of system and descriptive analysis, scientific abstraction, system approach. A brief analysis of the authors' works investigating this problem is given. System analysis is a scientific method of cognition, which is a sequence of actions to establish structural relationships between variables or constant elements of the system under study.

Descriptive method is a type of scientific method, which is a system of procedures for the collection, primary analysis and presentation of data and their characteristics. In the article the description precedes the in-depth (actually scientific) research, supplying samples and material for the deployment of further scientific procedures and methods regarding the harmonization of tax systems of the EAEU member States .

The method of scientific abstraction-a method of economic theory, which allows to exclude from the consideration of individual non-essential relationships between the subjects of the economy and focus on the consideration of several subjects. System approach in Economics is a methodological direction of scientific research, which consists in a comprehensive study of the economy as a whole from the standpoint of system analysis and synthesis. In this article, the harmonization of tax systems of the EAEU member States is considered from all sides of the economic aspects.

The purpose of this article is to conduct a comparative analysis of the tax systems of the members of the Eurasian economic union. The object of the study is the tax systems of the relevant countries. The results of the analysis can be used as additional information for future studies on the harmonization of tax systems of countries.

\section{Literature review}

The topic of harmonization of the tax systems of the countries of the Eurasian economic union began to be studied by scientists and economists more than 10 years ago, when the first steps towards 
the creation of the Customs Union were made. This topic was first considered by Russian economists.

Economists mainly focused on normative-legal acts, the differences in the mechanism of certain taxes, in particular VAT. On the other hand, a comparative analysis of the elements of the tax systems of individual countries-participants of the EAEC need for a harmonization process, therefore the topic of the article is relevant in the current economic conditions.

Economists A. Razin and E. Sadka consider the main approaches to the characterization of tax harmonization (Razin et al., 2015).

Analyzing the different approaches of scientists to the process of harmonization, we concluded that the most specific is the opinion of the Russian scientist Y. S. Rachinskaya, which offers to treat harmonisation as a systematic and purposeful activity of financial and tax services of the States, needed to overcome tax obstacles to sustainable economic growth, tax discrimination and stimulating the global integration processes (Rachinskaya, 2016).

According to M.I. Krotov, the Eurasian economic Union is the largest integration Association in the territory with a potential market capacity of $4-4.2 \%$ of world GDP. And the EAEU was created in order to comprehensively modernize, cooperate and improve the competitiveness of national economies and create conditions for stable development in order to improve the living standards of the population of the member States.

Also, Krotov predicts that in 10 years, by 2025 , the GDP of the EAEU countries only due to the integration effect should grow by $20 \%$ (Krotov, 2015).

A Russian economist E. G. Petrosian interprets that the study of the experience of the European Union in the field of harmonization of tax legislation shows that first of all it is necessary to regulate relations in the field of indirect taxation, in particular the collection of VAT and excise duties (Petrosian, 2016).

According to Gleason the newly established EAEC will have substantially stronger coordinating powers than its predecessors. According to the EAEC charter, the 20 organization will be empowered to represent the interests of the signatory states in international organizations (Gleason, 2003).

Unification of excise taxation does not provide for the introduction of common excise rates for excisable goods, it only requires a convergence of positions with respect to the list of taxable goods and the general level of taxation (Zorina, 2015).
The article also studied the works and studies of Russian and foreign scientists and economists.

\section{Results and discussion}

The role of harmonization of tax systems in the context of globalization and integration of the EAEU is noted. It was described a system of levying indirect taxes in the EAEU countries: practice, methods and problems. Ways of improving VAT within the EAEU countries in modern conditions are formed.

Tax harmonization is the systematization of taxation, unification of tax rates, coordination of tax systems, as well as tax administration of countries belonging to international regional groups and associations. The need to harmonize taxation is to unify the structures and principles of taxation, the general directions of tax reforms, the harmonization of tax policy and national law. All this is due to factors such as foreign economic relations between states. This relationship can have a beneficial effect on domestic legal regulation and economic relations in accordance with international principles and norms of economic law; foreign policy circumstances.

In the economic literature the following main approaches to the characteristic of tax harmonization are considered:

- tax harmonization as systematization and unification of taxes, coordination of tax systems and tax policies of countries;

- tax harmonization as unification, i.e. establishment of equal tax rates;

- tax harmonization as elimination of differences or inconsistencies between tax systems of different jurisdictions;

- tax harmonization as coordination and normative fixing of provisions of international treaties in the domestic legislation or changes of acts of the national legislation having the purpose of application of uniform norms and rules;

- tax harmonization as the creation of national financial systems corresponding to a number of common economic goals (Razin et al., 2015)

Analyzing the different approaches of scientists to the process of harmonization, we concluded that the most specific is the opinion of the Russian scientist Y.S. Rachinskaya, who offers to treat harmonisation as a systematic and purposeful activity of financial and tax services of the states, necessary for overcoming tax obstacles to sustainable economic growth, tax discrimination and stimulating the global integration processes (Rachinskaya, 2016). 
The Eurasian Economic Union is an international organization of regional economic integration with international legal personality and established by The Treaty on the Eurasian economic Union. The Eurasian economic Union began to operate on January 1, 2015.

In its development, the Eurasian economic integration has passed two stages: the Customs Union and the Common economic space and entered the stage of the Eurasian economic Union. After the adoption of the Customs code of the Customs Union in 2009, the Customs Union of Belarus, Kazakhstan and Russia functioned from 2010 to 2011. It was distinguished, firstly, by the application of a Single customs tariff and other measures of regulation of foreign trade in goods with third countries, secondly, the free movement of goods between the territories of the member States without the use of customs Declaration and state control (transport, sanitary, veterinary-sanitary, quarantine, phytosanitary), thirdly, the introduction of a mechanism for crediting and distributing the amounts of import duties, their transfer to the income of the budgets of the member States $(87 \%$ - Russian Federation, $7.25 \%$ - Kazakhstan, $4.65 \%$ - Belarus, $1.1 \%$ Armenia) (Krotov, 2015).

The success of the Customs Union allowed its participants to move to a higher level of integration: to form a single economic space from 2012 to 2014. It meant, firstly, the implementation of a coordinated macroeconomic policy to create a common market not only for goods, but also for services, capital and labor, and secondly, the creation of the Eurasian economic Commission as a regulatory body for the formation of a single economic space and, thirdly, the assignment to the court of EurAsEU in the format of judges from three States of the function of the Eurasian court. The entry into force of the EAEU Treaty made it possible to give Eurasian integration the necessary international legal form. The Eurasian economic Commission and the court of justice of the Eurasian Economic Union received the necessary legal personality as bodies of the EAEU. At this stage of Eurasian integration 71 barriers were removed and a program of gradual removal of the remaining barriers (229) was planned until 2025 (Krotov, 2015).

The EAEU ensures freedom of movement of goods, services, capital and labor, as well as coordinated or unified policy in the sectors of the economy.

Members of the Eurasian economic Union:

- Russia

- Belarus
- Kazakhstan

- Armenia

- Kyrgyzstan (The customs code of the EAEU)

The population of the above countries is 167 million, a total GDP of USD2 trillion and a goods turnover of USD 900 billion (Krotov, 2011).

The main aims of Customs Union and Common Economic Area:

- Enhancement of tax cooperation;

- Ensuring the economic security;

- Enhancement of cooperation in respect of migrant workers;

- Development of supranational institutions (Tyutyuryukov, 2015).

The signatories strongly supported the idea of maintaining closely coordinated CIS-wide economic policies through common monetary, customs, employment, tax, and investment policies (Gleason, 1992).

The Eurasian economic Union is the largest integration Union with a potential market capacity of $4-4.2 \%$ of world GDP (Krotov, 2015). The EAEU was created in order to comprehensively modernize, cooperate and improve the competitiveness of national economies and create conditions for stable development in order to improve the living standards of the population of the member States.

The EAEC is substantially different from its predecessors. First of all, The EAEC arrangements include a weighted voting and 19 financing scheme (Islamova, 2001).

The newly established EAEC will have substantially stronger coordinating powers than its predecessors. According to the EAEC charter, the 20 organization will be empowered to represent the interests of the signatory states in international organizations (Gleason, 2003).

As an organization, the EAEU consists of several governing bodies, in which member states are equally represented. These are the Supreme Council (meeting at the level of heads of state), the Intergovernmental Council (meeting at the level of heads of government), and the two-tier Eurasian Economic Commission (Dragneva et al., 2017).

The Supreme governing body is the Supreme Council, which consists of the heads of member states. Next is the intergovernmental Council. It consists of Prime Ministers whose main task is to consider strategic issues of economic integration. A judicial body has also been established, which is responsible for the use of contracts within the Union. The Eurasian Economic Commission (EEC) is a regulatory body that provides all conditions for the development and functioning of the Union, 
as well as the development of new proposals in the economic sphere for the EAEU (Musina et al., 2015).

For 10 years, by 2025, the GDP of the EAEU countries should grow by $20 \%$ only due to the integration effect. This, of course, will be facilitated by the targeted development of intra-Eurasian competition on the basis of creating equal economic conditions for business structures and employees of the EAEU member States. Thus, the competition of customs services has significantly accelerated and simplified customs clearance. Competition of jurisdictions leads to the transfer of capital to countries with better economic conditions. For example, VAT in Kazakhstan is about $12 \%$, in the Russian Federation $-18 \%$, in Armenia - 20\%. It is obvious that over time the Eurasian tax legislation should be harmonized and even unified (Krotov, 2015).

The entry into Force of the Treaty on the establishment of the EAEU led to the simultaneous abolition of the preceding regional economic Association - the Eurasian economic community (EurAsEC) (Pazilov, 2016).

The study of the experience of the European Union in the field of harmonization of tax legislation shows that firstly it is necessary to regulate relations in the field of indirect taxation, in particular the collection of VAT and excise taxes. This is due to the significant role of these taxes in pricing in mutual trade between the countries, as well as their share in the tax revenues of the participating countries (Petrosian, 2016).

Within the EAEU, free movement of goods, services, capital and labor is ensured, as well as coordinated or unified policy in the sectors of the economy defined by the EAEU Treaty and international treaties within the EAEU (Ivanova, 2016).

The agreement defines the tax base for the purposes of VAT and excise duties on imports of goods, and when importing works and services, the tax base, indirect tax rates, the procedure for their collection and tax benefits (tax exemption) are determined in accordance with the legislation of the country whose territory is recognized as the place of sale of works or services.

The Treaty provides that the rates of indirect taxes in mutual trade when importing goods into the territory of a member state shall not exceed the rates of indirect taxes imposed on similar goods when they are sold in the territory of that country, but does not specify the minimum rates to be applied by member States, as it is done in the EU, where the minimum rates of indirect taxation for all member States are established (Petrosian, 2016).
The most significant in the system of customs payments are, of course, customs duties (import and export) and taxes (VAT and excise duties levied by the customs authorities when importing goods into the customs territory of the customs Union) (Sbezhnev, 2016).

Nevertheless, the Agreement specifies the conditions under which indirect taxes will not be levied when importing to the territory of the EAEU member state. These rules will help to avoid:

- unfair and price competition;

- double taxation of VAT on the import by individuals of goods for personal consumption;

- double taxation of VAT in the transfer of inventory by structural units of one legal entity located in different member States of the EAEU.

The table 1 shows the VAT rates of the EAEU members.

As can be seen from the data in table 1, each country has its own policy regarding VAT collection. The amounts of indirect taxes payable on goods imported into the territory of one member state from the territory of another member state shall be calculated by the taxpayer at the tax rates established by the legislation of the member state in the territory of which the goods are imported. But despite the differences in rates, the list of goods to which the reduced VAT rates apply is practically the same: it is the export of goods and services and international transportation.

Analysis of the structure of tax revenues shows that VAT is one of the main taxes. As it is shown in table 2.

As can be seen from table 2, VAT accounts for more than $25 \%$ of all tax revenues in the countries, so we support the opinion of scientists that the harmonization of tax systems should start with VAT. Here, in our opinion, the experience of the EU countries is interesting. VAT can be considered the main budget-forming tax.

The practice of VAT collection, studied by scientists allowed to highlight the following:

- in all five countries there is no single VAT rate, preferential rates or conditions of exemption from value added tax are allocated;

- in all EAEU members VAT is charged at the place of registration;

- VAT amounts paid on goods imported from the EAEU members are subject to deductions in the General order;

- the right to deduct VAT arises from the taxpayer-importer not earlier than the period in which VAT on imported goods is paid and reflected in the relevant tax Declaration and application for import of goods (Murzagaliev, 2015). 
Table 1 - VAT rates in the EAEU countries, 2017

\begin{tabular}{|c|c|c|c|c|}
\hline Country & $\begin{array}{l}\text { Total rate } \\
\quad(\%)\end{array}$ & Tax base for application of reduced rate & $\begin{array}{l}\text { Reduced rate } \\
(\%)\end{array}$ & $\begin{array}{l}\text { Non-taxable } \\
\text { level }\end{array}$ \\
\hline Republic of Kazakhstan & 12 & $\begin{array}{l}\text { Export of goods and services. International } \\
\text { transportation services, etc. }\end{array}$ & 0 & - \\
\hline \multirow[b]{2}{*}{ Russian Federation } & \multirow[b]{2}{*}{18} & $\begin{array}{l}\text { Sales of goods for children, printed periodicals and } \\
\text { books, medical goods }\end{array}$ & 10 & - \\
\hline & & $\begin{array}{l}\text { Export of goods and services, as well as goods subject } \\
\text { to the free customs zone. International transportation } \\
\text { services }\end{array}$ & 0 & - \\
\hline \multirow{4}{*}{ Republic of Belarus } & \multirow{4}{*}{20} & $\begin{array}{l}\text { Realization of the products of plant growing, animal } \\
\text { husbandry, fish farming and beekeeping produced in } \\
\text { the Republic of Belarus }\end{array}$ & 10 & - \\
\hline & & $\begin{array}{l}\text { Sale of goods at recommended retail prices including } \\
\text { VAT }\end{array}$ & 9,09 and 16,67 & - \\
\hline & & $\begin{array}{l}\text { Import from the CU member States of diamonds and } \\
\text { other precious stones for production needs }\end{array}$ & 0,50 & - \\
\hline & & Export of goods and services & 0 & - \\
\hline Republic of Armenia & 20 & $\begin{array}{l}\text { Export of goods and services, international } \\
\text { transportation services, etc. }\end{array}$ & 0 & 140534,7 doll. \\
\hline Republic of Kyrgyzstan & 12 & Export of goods and services, etc. & 0 & 74539,3 doll. \\
\hline
\end{tabular}

Table 2 - The share of VAT in the tax revenues of the EAEU members for 2017

\begin{tabular}{|c|c|c|c|c|c|}
\hline Country & $\begin{array}{c}\text { Republic of } \\
\text { Kazakhstan }\end{array}$ & Russian Federation & Republic of Belarus & $\begin{array}{c}\text { Republic of } \\
\text { Kyrgyzstan }\end{array}$ & $\begin{array}{c}\text { Republic of } \\
\text { Armenia }\end{array}$ \\
\hline Tax revenue & 6810,8 (bln tenge) & 19139,8 (bln rub) & 26,3 (bln rub) & 91,5 (bln som) & 1,115 (trln dram) \\
\hline VAT & 1664,7 (bln tenge) & 5137,6 (bln rub) & 9,2 (bln rub) & 23,4 (bln som) & 0,27 (trln dram) \\
\hline $\begin{array}{l}\text { The share of VAT in } \\
\text { tax revenue }\end{array}$ & $24,44 \%$ & $34,9 \%$ & $25,6 \%$ & $24,8 \%$ \\
\hline $\begin{array}{l}\text { Sources: Federal state statistics service of the Russian Federation, Ministry of national economy. The statistics Committee, National } \\
\text { statistical Committee of the Kyrgyz Republic, National statistical Committee of the Republic of Belarus, Statistical Committee of } \\
\text { the Republic of Armenia }\end{array}$
\end{tabular}

Analysis of VAT in the framework of the EAEU allows noting the following problems:

1.Different terminology when defining the objects of the VAT, different list of components of objects of the VAT, and also objects that are not objects of VAT taxation;

2.Different conditions for the application of tax deductions (offset) of VAT amounts, as well as different methods for calculating the amounts of VAT to be deducted (offset)

3. Significant differentiation of VAT rates applied in the member States of the Eurasian economic Union $(12 \%, 18 \%, 20 \%)$.

Non-tariff barriers form a strong impediment to free trade in the EAEU. The ad valorem equivalents of such barriers range from 10-30 per cent of some countries' export value (Vinokurov, 2016).

Taking into account the special importance of VAT in the implementation of foreign trade, to solve the problems of unification of the tax legislation of the member States of the Eurasian economic Union it is necessary:

1. Use uniform terminology in determining the objects of value-added taxation (the experience of the Republic of Kazakhstan, namely, taxable turnover and taxable imports can be taken as a basis);

2.Fix the identical list of objects of value added tax, as well as objects that are not objects of VAT taxation; 
3.Provide for the possibility of establishing by the tax legislation features of determining the tax base for the sale of goods (works, services) at regulated prices (tariffs);

4.Establish an identical method of determining the tax base when importing goods into the customs territory. The norms of the Tax code of the Republic of Kazakhstan can be taken as a basis, according to which the tax base is defined as the amount of customs value of imported goods, determined in accordance with the customs legislation of the relevant state, as well as payable to the budget amounts of taxes, fees (duties) on imports, except for value added tax;

5.Determine the unified conditions for the application of tax deductions (offset) of value added tax amounts, as well as use the unified methods for calculating the amounts of value added tax to be deducted (offset);

6. Due to the significant differentiation of the value added tax rates applied in the member States of the Eurasian Economic Union (12\%, 18\%, 20\%) it is justified to take measures to equalize the value added tax rates and to establish a single minimum rate of $9 \%$.

In the process of harmonization of tax legislation at a certain stage there is a need for unification of the list and composition of excisable products. Too large differences in excise tax rates for excisable goods in States that integrate lead to a violation of the principle of competitive equality. Therefore, in order to prevent deep gaps in the level of taxation of excisable goods, it is necessary to conduct a coordinated state policy in the EAEU members (Mambetaliev, 2015).

At the same time, unification of excise taxation does not provide for the introduction of common excise rates for excisable goods, it only requires a convergence of positions with respect to the list of taxable goods and the general level of taxation (Zorina, 2015).

To have a complete picture of the harmonization of the tax systems of the EAEU countries, it is necessary to first consider and compare the elements of the tax systems of these countries.

Table 3 presents a comparative analysis of some elements of the tax systems of the countries of the Eurasian economic Union, namely: levels of the tax system, types of taxes, composition of tax authorities, special tax regimes. Basically, the tax systems of the above countries consist of two and three levels.

A large number of types of taxes observed in the Republic of Kazakhstan and the Republic of Belarus. Despite the fact that the legislation of Kazakhstan has provided for a large number of different taxes and fees, it should be noted that the rates for basic payments to the budget (income taxes, VAT, excise taxes, etc.) are low compared not only with other CIS countries, but also with the world.

The Russian Federation is a Federal Republic, so in addition to local and Federal authorities, it also has a regional one. In this regard, the tax system in Russia is a three-stage level, taxes are divided into Federal, regional and local. Unitary Armenia is divided into municipalities, so the tax system has only two stages. Apparently, in this regard, the total number of taxes in Russia is much more than in Armenia (only eight Federal taxes against four state taxes in Armenia). However, it should be noted that the rates for some Russian taxes are much lower than Armenian ones. Thus, in Russia the minimum income tax rate is thirteen percent, in Armenia 24.4 percent; the minimum VAT rate is ten percent, and in Armenia - twenty percent.

The structure of the tax authorities of the five countries is also similar. All tax authorities of the countries are subordinated to the Ministries of Finance of the respective republics.

Many tax benefits and special tax regimes are most observed in the Republic of Kyrgyzstan and the Republic of Belarus. Some types of special tax regimes do not have taxes in other countries. For example, such as: taxes on the basis of a tax contract; tax regime in free economic zones; tax on special funds; tax regime in the hi-tech Park (the Republic of Kyrgyzstan).

As a result of this analysis, it can be concluded that the main problems for the harmonization of tax systems of the EAEU countries are a variety of special tax regimes and tax benefits, preferences, as well as types and interest rates of taxes. To fully solve these problems, it is predicted that joint system work is required for at least 5-10 years. Only after that we can get the necessary results of system harmonization. 
Ermekbaeva B.Zh., Mukhadil Zh.E.

Table 3 - Comparative analysis of some elements of the tax systems of the EAEU countries

\begin{tabular}{|c|c|c|c|c|c|}
\hline $\begin{array}{l}\text { Elements } \\
\text { of the tax system }\end{array}$ & $\begin{array}{l}\text { Republic of } \\
\text { Kazakhstan }\end{array}$ & Russian Federation & $\begin{array}{l}\text { Republic of } \\
\text { Kyrgyzstan }\end{array}$ & Republic of Belarus & $\begin{array}{l}\text { Republic of } \\
\text { Armenia }\end{array}$ \\
\hline $\begin{array}{l}\text { Levels of the tax } \\
\text { system }\end{array}$ & $\begin{array}{l}\text { - republican level; } \\
\text { - regional level; } \\
\text { - district level }\end{array}$ & $\begin{array}{l}\text { - federal level; } \\
\text { - regional level; } \\
\text { - local level }\end{array}$ & $\begin{array}{l}\text { - republican level } \\
\text { - local level }\end{array}$ & $\begin{array}{l}\text { - republican level } \\
\text { - local level }\end{array}$ & $\begin{array}{l}\text { - state level } \\
\text { - local level }\end{array}$ \\
\hline Type of taxes & $\begin{array}{l}\text { Income taxes: } \\
\text { Corporate income } \\
\text { tax; Individual } \\
\text { income tax; Social } \\
\text { tax Property taxes: } \\
\text { property Taxes; } \\
\text { Land tax; Single } \\
\text { land tax; Vehicle } \\
\text { tax; taxes on goods, } \\
\text { works, services } \\
\text { produced within the } \\
\text { country or imported } \\
\text { into the country; } \\
\text { VAT; excise Taxes; } \\
\text { Gambling tax; } \\
\text { Fixed tax } \\
\text { Foreign trade and } \\
\text { foreign trade taxes: } \\
\text { Tax on rent and } \\
\text { export }\end{array}$ & $\begin{array}{l}\text { Federal taxes: } \\
\text { tax on income of } \\
\text { individuals; income } \\
\text { tax; VAT; excise; } \\
\text { water tax; mineral } \\
\text { extraction tax; state } \\
\text { duty. } \\
\text { Local taxes: land } \\
\text { tax; property tax of } \\
\text { individuals; trade } \\
\text { tax. }\end{array}$ & $\begin{array}{l}\text { State taxes: Income } \\
\text { tax; value added } \\
\text { tax; Excise tax; } \\
\text { subsoil use Tax; } \\
\text { sales Tax. } \\
\text { Local taxes: } \\
\text { Property tax; Land } \\
\text { tax }\end{array}$ & $\begin{array}{l}\text { Republican taxes: } \\
\text { value added tax; } \\
\text { excise taxes; } \\
\text { income tax; income } \\
\text { tax on individuals; } \\
\text { environmental } \\
\text { tax; taxes on } \\
\text { users of natural } \\
\text { resources; property } \\
\text { taxes; tax on } \\
\text { income of foreign } \\
\text { organizations; } \\
\text { Land tax; tax } \\
\text { on extraction } \\
\text { (withdrawal) of } \\
\text { natural resources. } \\
\text { Local taxes: retail } \\
\text { sales tax; service } \\
\text { tax; advertising tax }\end{array}$ & $\begin{array}{l}\text { State taxes: income } \\
\text { Tax; Excise tax; } \\
\text { value added Tax } \\
\text { Local taxes: } \\
\text { property Tax; Land } \\
\text { tax; Hotel tax; } \\
\text { vehicle Parking tax }\end{array}$ \\
\hline $\begin{array}{l}\text { The structure of the } \\
\text { tax authorities }\end{array}$ & $\begin{array}{l}\text { - Ministry of } \\
\text { Finance of The } \\
\text { Republic Of } \\
\text { Kazakhstan } \\
\text { - State revenue } \\
\text { Committee of the } \\
\text { Ministry of Finance } \\
\text { of the Republic of } \\
\text { Kazakhstan }\end{array}$ & $\begin{array}{l}\text { - Ministry of } \\
\text { Finance of The } \\
\text { Russian Federation } \\
\text { - Federal tax service } \\
\text { of the Russian } \\
\text { Federation }\end{array}$ & $\begin{array}{l}\text { - Ministry of } \\
\text { Finance of the } \\
\text { Kyrgyz Republic } \\
\text { - State tax } \\
\text { service under the } \\
\text { Government of the } \\
\text { Kyrgyz Republic }\end{array}$ & $\begin{array}{l}\text { - Ministry of } \\
\text { Finance of The } \\
\text { Republic of Belarus } \\
\text { - Ministry of taxes } \\
\text { and duties and } \\
\text { - State control } \\
\text { committee } \\
\text { - State customs } \\
\text { committee }\end{array}$ & $\begin{array}{l}\text { - Ministry of } \\
\text { Finance of The } \\
\text { Republic of } \\
\text { Armenia } \\
\text { - Tax Service of } \\
\text { The Republic of } \\
\text { Armenia }\end{array}$ \\
\hline Special tax regime & $\begin{array}{l}\text { - special tax regime } \\
\text { based on patent; } \\
\text { - special tax regime } \\
\text { based on simplified } \\
\text { Declaration; } \\
\text { - special tax regime } \\
\text { for peasant or farm } \\
\text { households }\end{array}$ & $\begin{array}{l}\text { - a single tax on } \\
\text { imputed income; } \\
\text { - unified } \\
\text { agricultural tax; } \\
\text { - simplified tax } \\
\text { system; } \\
\text { - patent system. }\end{array}$ & $\begin{array}{l}\text { - simplified tax } \\
\text { system based on a } \\
\text { single tax; } \\
\text { - tax on the basis of } \\
\text { a mandatory patent; } \\
\text { - tax on the basis of } \\
\text { a voluntary patent; } \\
\text { - taxes based on the } \\
\text { tax contract; } \\
\text { - tax regime in free } \\
\text { economic zones; } \\
\text { - tax on special } \\
\text { means; } \\
\text { - tax regime in the } \\
\text { hi-tech Park }\end{array}$ & $\begin{array}{l}\text { - simplified tax } \\
\text { system } \\
\text { - single taxes: } \\
\text { from individual } \\
\text { entrepreneurs and } \\
\text { other individuals, } \\
\text { for agricultural } \\
\text { producers } \\
\text { - fee for the } \\
\text { implementation } \\
\text { of: craft activities, } \\
\text { activities in the field } \\
\text { of agroecotourism } \\
\text { - a single tax on } \\
\text { imputed income }\end{array}$ & $\begin{array}{l}\text { Simplified tax } \\
\text { A simplified tax } \\
\text { is a business tax } \\
\text { that replaces value } \\
\text { added tax (VAT) } \\
\text { and income tax. } \\
\text { For legal entities, } \\
\text { the simplified } \\
\text { tax replaces VAT } \\
\text { and income tax. } \\
\text { For individual } \\
\text { entrepreneurs, } \\
\text { the simplified tax } \\
\text { replaces VAT and } \\
\text { income tax. }\end{array}$ \\
\hline
\end{tabular}

\section{Conclusion}

It should be noted that it is too early to consider that the tax systems of the members of EAEU are perfect. There are many problems in the content, structure, methods and forms of taxation. In this regard, it is legitimate to start the harmonization of tax systems not by equalizing the number of taxes, but by assessing the effectiveness of the tax systems of the integrating States, and developing a coherent tax policy that meets the interests of all members of the economic Union. 
The further strategy of the EAEU members should be aimed at the implementation of a coordinated tax policy that stimulates the development of national economies, including the improvement of tax legislation and administration. The proposed measures will enhance the competitiveness of economic entities and eliminate tax barriers affecting the development of economic relations between the EAEU members.

Being one of the main factors determining the socio-economic situation of the country, tax policy has a significant impact on the competitiveness of the country in the international area. However, in a rapidly developing world, where the national economy is faced with the expansion of operations of transnational companies, with the rapid development of communications, with the birth and spread of new business models, the tax policy of the individual state is unable to cope with all the challenges alone. Further development of the integration processes of the EAEU and the corresponding harmonization of tax policy are necessary to improve the competitiveness of the participating countries in the world market.
Based on the analysis, we can formulate the following recommendations concerning the development of relations between the EAEU countries in the field of taxation:

- development of the basic principles of tax harmonization of individuals and legal entities on the territory of the EAEU members (just as it is done in the EU, where these principles include the absence of discrimination, proportionality, legal certainty and prevention of unjustified enrichment);

- increasing the level of information exchange and cooperation between the tax authorities of the EAEU countries in the field of both indirect and direct taxation;

- establishment of common terminology for the main types of taxes;

- the establishment of the basic provisions and principles relating to all taxes, not bilateral agreements and conventions, and international treaties of the EAEU, but each type of tax must comply with a separate treaty;

- convergence of positions on the list of excisable goods.

\section{References}

Agreement about the Customs code of the Eurasian economic Union (EAEU CC) of April 11, 2017. - Access mode: http:// tkeaes.ru

Dragneva R., Wolczuk, K. The Eurasian Economic Union. Deals, rules and the exercise of power. - 2017. - vol. 3.

Federal state statistics service of the Russian Federation. - Access mode: http://www.gks.ru/

Gleason G. The Reintegration of Eurasia: Functional Theory and Interstate Policy Coordination. Panel Of the European Union and Post-Communist Space. - 2003.

Gleason G. The Federal Formula and the Collapse of the USSR // The Journal of Federalism. - 1992. - vol. 22, pp. 141-163.

Islamova G. Eurasian Economic Community: Purposes, Challenges And Prospects // Central Asia and the Caucasus. - 2001. vol. 7 (1).

Krotov I. Customs Union between the Republic of Belarus, the Republic of Kazakhstan and the Russian Federation within the framework of the Eurasian Economic Community // World Customs Journal. - 2011. - vol. 5 (2), p. 133.

Ministry of national economy. The statistics Committee. - Access mode: http://stat.gov.kz/

National statistical Committee of the Kyrgyz Republic. - Access mode: http://www.stat.kg/ru/

National statistical Committee of the Republic of Belarus. - Access mode: http://www.belstat.gov.by/

Razin A., Sadka E. International tax competition and gains from tax Harmonization. - 2015. - Access mode: http: //www.nber. org/ppaers/w 3152

Statistical Committee of the Republic of Armenia. - Access mode: https://www.armstat.am/ru/

Tax code of the Russian Federation (TC RF) N 146-FZ of July 31, 1998. - Access mode: http://www.russian-tax-code.com/

Tax code of the Republic of Kazakhstan «On taxes and other obligatory payments to the budget (Tax Code)» December 25, 2017 № 120-VI, has been amended by the 2018. - Access mode: https://online.zakon.kz/Document/?doc_id=36575067\#pos=0;200

Tax code of the Republic of Belarus (Law of the Republic of Belarus «About modification and additions in some laws of the Republic of Belarus», № 159-Z of 30 december 2018. - Access mode: http://www.nalog.gov.by/ru/TAX_CODE_RU/

Tax code of the Republic of Kyrgyzstan, No. 230 of October 17, 2008 (the last edition from 07.03.2019). - Access mode: http:// cis-legislation.com/document.fwx?rgn=24860

Tax code of the Republic of Armenia, №ZP-165 of November 1, 2016. - Access mode: http://base.spinform.ru/show_doc. fwx?rgn=102854

Tyutyuryukov V. Excises and Budget Sustainability: The Lessons from Eurasian Economic Union // Proceedings of conference «Financial stability and sustainable growth in European Union: modern state and perspectives. - 2015.

Vinokurov E. et al. Assessing the impact of non-tariff barriers in the EEU: Results of enterprise surveys. - EDB Centre for Integration Studies Report \#30. - 2016. 
Зорина Р.С. Перспективы гармонизации налогового законодательства стран-участниц ЕАЭС // Законодательство. 2015. - № 7, C. 47-82.

Иванова Т. ЕАЭС: особенности обложения косвенными налогами // Файл бухгалтера. - 2016. - №16 (786). с. 2.

Кротов М.И. Евразийский экономический союз: история, особенности, перспективы // Журнал Управленческое консультирование. - 2015. - №11 (83). - С. 33-35.

Мамбеталиев Н.Т. Налоги и налогообложение в Евразийском экономическом союзе // Налоговая политика и практика. - 2015. - № 5. - С. 78-80.

Мурзагалиев Е.Ч. Налоговое законодательство стран-членов Евразийского экономического союза: проблемы конкурентоспособности и унификации // Актуальные проблемы гуманитарных и естественных наук. - 2015. - № (8-2). C. $55-58$.

Мусина Д.Р., Латыпов Р.В. Таможенный союз как фактор развития экономики России // Журнал Инновационная наука. $-2015$.

Пазилов Б.К. Киргизия в евразийском экономическом союзе: предпосылки, первые результаты и перспективы // Журнал: Власть. - 2015. - №4.

Петросян Е.Г. Пути гармонизации систем налогообложения в странах Евразийского эконмического союза // Журнал Экономическая политика. - 2016. - №6. - том 11. - С. 227-228.

Рачинская Ю.С. Особенности и тенденции налоговой гармонизации (на примере стран ЕС, СНГ и ТС): Автореферат на соискание ученой степени к.э.н. - М. - 2016. - Режим доступа: http: //dis.podelise.ru/pars docs/diser-refs 73/72281

Сбежнев В.А. Таможенные сборы в Евразийском экономическом союзе // Журнал: Вестник Финансового университета. - 2016. - №1 (91).

\section{References}

Agreement about the Customs code of the Eurasian economic Union (EAEU CC) of April 11, 2017. Access mode: http://tkeaes. $\mathrm{ru}$

Dragneva R., Wolczuk, K. (2017) The Eurasian Economic Union. Deals, rules and the exercise of power, vol. 3.

Federal state statistics service of the Russian Federation. Access mode: http:/www.gks.ru/

Gleason G. (1992) The Federal Formula and the Collapse of the USSR. The Journal of Federalism, vol. 22, pp. 141-163.

Gleason G. (2003) The Reintegration of Eurasia: Functional Theory and Interstate Policy Coordination. Panel Of the European Union and Post-Communist Space.

Ivanova T. (2016) EAES: osobennosti oblozhenia kosvennymi nalogami [EAEU: features of indirect taxation]. File of accountant, vol. 16 (786), p. 2.

Islamova G. (2001) Eurasian Economic Community: Purposes, Challenges and Prospects. Central Asia and the Caucasus, vol. $7(1)$.

Krotov I. (2011) Customs Union between the Republic of Belarus, the Republic of Kazakhstan and the Russian Federation within the framework of the Eurasian Economic Community. World Customs Journal, vol. 5(2), p. 133.

Krotov M.I. (2015) Evraziyskiy ekonomicheskiy souz: istoria, osobennosti, persperkivy [Eurasian economic Union: history, features, prospects]. Journal of Management consulting, vol. 11 (83), pp. 33-35.

Mambetaliev N.T. (2015) Nalogi I nalogooblozhenie v Evraziyskom ekonomicheskom souze [Taxes and taxation in the Eurasian economic Union]. Tax policy and practice, vol. 5, pp. 78-80.

Ministry of national economy. The statistics Committee. Access mode: http://stat.gov.kz/

Murzagaliev E.C. (2015) Nalogovoe zakonodatelstvo stran-chlenov Evraziyskogo ekonomicheskogo souza: problem konkurentosposobnosti I unifikacii [Tax legislation of the member States of the Eurasian economic Union: problems of competitiveness and unification]. Actual problems of Humanities and natural Sciences, vol. 8-2, pp. 55-58

Musina D.R., Latypov R.V. (2015) Tamozhennyi souz kak factor razvitia ekonomuku Rossii [Customs Union as a factor in the development of the Russian economy]. Journal of Innovative science.

National statistical Committee of the Kyrgyz Republic. Access mode: http://www.stat.kg/ru/

National statistical Committee of the Republic of Belarus. Access mode: http://www.belstat.gov.by/

Pazilov B.K. (2016) Kirgizia v evraziyskom souse: predposylki, pervye rezultaty I perspektivy [Kyrgyzstan in the Eurasian economic Union: prerequisites, first results and prospects]. Journal Power, vol. 4

Petrosian E.G. (2016) Puti garmonizcii system nalogooblozhenia v stranah Evraziyskogo ekonomicheskogo souza [Ways of harmonization of tax systems in the countries of the Eurasian economic Union]. Journal of Economic policy, vol. 6, issue 11, pp. 227-228

Rachinskaya Y.S. (2016) Osobennosti I tendencii nalogovoi garmonizacii (na primere stran ES, SNG, TS) [Features and trends of tax harmonization (on the example of the EU, the CIS and the customs Union)] Abstract for the degree of candidate of economic Sciences. Access mode: http: //dis.podelise.ru/pars docs/diser-refs 73/72281

Razin A., Sadka E. (2015) International tax competition and gains from tax Harmonization. Access mode: http: //www.nber.org/ ppaers/w 3152

Sbezhnev B.A. (2016) Tamozhennye sbory v Evraziyskom ekonomicheskom souse [Customs duties in the Eurasian economic Union]. Bulletin of the Financial University, vol. 1 (91).

Statistical Committee of the Republic of Armenia. Access mode: https://www.armstat.am/ru/

Tax code of the Russian Federation (TC RF) N 146-FZ of July 31, 1998. Access mode: http://www.russian-tax-code.com/ 
The code of the Republic of Kazakhstan «On taxes and other obligatory payments to the budget (Tax Code)», 25 December, 2017 № 120-VI, has been amended by the 2018. Access mode: https://online.zakon.kz/Document/?doc_id=36575067\#pos=0;200

Tax code of the Republic of Belarus (Law of the Republic of Belarus «About modification and additions in some laws of the Republic of Belarus», № 159-Z of 30 december 2018). Access mode: http://www.nalog.gov.by/ru/TAX_CODE_RU/

Tax code of the Republic of Kyrgyzstan, No. 230 of October 17, 2008 (the last edition from 07.03.2019). Access mode: http:// cis-legislation.com/document.fwx?rgn=24860

Tax code of the Republic of Armenia, №ZP-165 of November 1, 2016. Access mode: http://base.spinform.ru/show_doc. fwx?rgn=102854

Tyutyuryukov V. (2015) Excises and Budget Sustainability: The Lessons from Eurasian Economic Union. Proceedings of conference «Financial stability and sustainable growth in European Union: modern state and perspectives.

Vinokurov E. et al. (2016) Assessing the impact of non-tariff barriers in the EAEU: Results of enterprise surveys. EDB Centre for Integration Studies Report \#30.

Zorina R.S. (2015) Perspektiva garmonizacii nalogovogo zakonodatelstva stran-uchastnic EAES [Prospects for harmonization of tax legislation of the EAEU members]. Legislation, vol. 7, pp. 47-82 